Radosław Zenderowski

Instytut Politologii

Uniwersytet Kardynała Stefana Wyszyńskiego w Warszawie

Andrzej Rudowski

Instytut Politologii

Uniwersytet Kardynała Stefana Wyszyńskiego w Warszawie

DOI: $10.19195 / 2450-274 X .3 .10$

\title{
Europa Środkowa - od idei literacko-kawiarnianej do koncepcji politycznych
}

Abstrakt: Europa Środkowa stanowi zarówno ideę wspólnoty kulturowej, przestrzeń geopolityczną i geokulturową, jak i pewną koncepcję polityczną. W ostatnich kilku dekadach jesteśmy świadkami przejścia (czy raczej interferencji) od idei literacko-kawiarnianej ku politycznym formom instytucjonalizacji Europy Środkowej. Celem niniejszego artykułu jest ukazanie owej drogi oraz kluczowych dylematów stojących przed architektami politycznej Europy Środkowej. W artykule omówiono zatem dyskurs środkowoeuropejski w latach 70. i 80. XX w., a następnie poszczególne uwarunkowania i etapy politycznej instytucjonalizacji Europy Środkowej z naciskiem na okres po 2004 r.

Słowa kluczowe: Europa Środkowa, integracja, instytucjonalizacja

\section{Central Europe - from the café literary idea to political concepts}

Abstract: Central Europe is both an idea of a cultural community, a geopolitical and geocultural space, as well as a concrete political concept. In the last decades, we are the witnesses of transition (or rather an interference) from the literary-cafeteria idea towards the political forms of institutionalization of Central Europe. The aim of this article is to show this way and key dilemmas facing the political architects of Central Europe. The article discusses the Central European discourse in the 70 s and 80 s of the 20th century, and then the various conditions and stages of the political institutionalization of Central Europe with an emphasis on the period after 2004.

Keywords: Central Europe, integration, institutionalisation 


\section{Wstęp}

Europa Środkowa stanowi zarówno ideę wspólnoty kulturowej, przestrzeń geopolityczną i geokulturową, jak i pewną koncepcję polityczną. Przez ostatnie kilka dekad jesteśmy świadkami przejścia (czy raczej interferencji) od idei literacko-kawiarnianej ku politycznym formom instytucjonalizacji Europy Środkowej. Celem niniejszego artykułu jest ukazanie owej drogi oraz kluczowych dylematów stojących przed architektami politycznej Europy Środkowej.

\section{Dyskurs środkowoeuropejski w latach 70. i 80. XX w.}

„I znów mamy Europę Środkową. Poczynając od roku 1945, przez trzy dziesięciolecia nikt nie mówił o niej w czasie teraźniejszym. Dzieliła los Niniwy i Tyru"1 — od tego zdania zaczyna swoją analizę odradzającego się fenomenu Europy Środkowej Timothy Garton Ash w eseju pt. Czy Europa Środkowa istnieje?.

W latach 70. i 80. XX w. w Polsce, Czechosłowacji i na Węgrzech w różnego rodzaju dyskursach coraz częściej pojawiało się pojęcie Europy Środkowej. Termin, który dziś uznajemy za naturalny i najlepiej określający geopolityczną i kulturowo-cywilizacyjną tożsamość wspomnianych państw, do końca lat 80. XX w. uznawany był przez władze komunistyczne za przejaw antyreżimowej kontestacji. Dowodem na to było choćby wpisanie przez redakcje „Trybuny Ludu” terminu „Europa Środkowa” do nieformalnego indeksu słów zakazanych. W trakcie zimnej wojny obowiązywał bowiem dualistyczny i manichejski podział Europy. Z jednej strony, była to kapitalistyczna i liberalno-demokratyczna Europa Zachodnia, z drugiej - socjalistyczna i ludowo-demokratyczna Europa Wschodnia. Ów trwający kilka dekad podział Europy był przez wielu polityków, lecz także intelektualistów czy zwykłych ludzi z obydwu stron granicy, której symbolem był mur berliński, postrzegany jako oczywisty i w zasadzie nienaruszalny ${ }^{2}$. Notabene żelazna kurtyna zapadła niemal dokładnie w tym samym miejscu (z niewielkim odchyleniem w Turyngii), gdzie ponad jedenaście wieków wcześniej przebiegały wschodnie granice państwa Karola Wielkiego ${ }^{3}$.

Nie można przy tym nie zauważyć, że termin ten był nie tylko konsekwencją powojennej konfrontacji USA-ZSRR, ale przede wszystkim wpisywał się w zachodnią, oświeceniową tradycję orientalizującego dyskursu stworzonego głównie przez francuskich i niemieckich myślicieli, którego celem było wykreowanie mitu

1 T.G. Ash, Czy Europa Środkowa istnieje?, „Zeszyty Literackie” 1987, nr 17, s. 25.

2 A. Czarnocki, Europa Środkowa. Europa Środkowo-Wschodnia: geopolityczne a historyczno-kulturowe rozumienie pojęć, „Annales Universitatis Mariae Curie-Skłodowska. Sectio K: Politologia” 1994, nr 1, s. 23.

3 R. Zenderowski, Pomiędzy Wschodem a Zachodem?, „Przegląd Zachodni” 2004, nr 3, s. 5. 
niecywilizowanego, barbarzyńskiego i nacechowanego chaosem Wschodu, aby uwiarygodnić cywilizacyjną przewagę Zachodu. Zgodnie z tą stygmatyzującą narracją, świetnie zdiagnozowaną i opisaną przez Edwarda Saida w książce pt. Orientalism (1978) oraz Larry'ego Wollfa w publikacji pt. Inventing Eastern Europe: The Map of Civilization on the Mind of the Enlightenment (1994),

Zachód do konsolidacji własnego optymistycznego wizerunku jako ucieleśnienia oświeceniowych ideałów postępu „potrzebował” słabiej rozwiniętego, nieucywilizowanego, zacofanego i niedojrzałego Innego, którego musiał odpowiednio przedstawić i nazwać, a więc wyposażyć w przypisaną mu przez siebie tożsamość 4 .

Ten rodzaj ideologicznej narracji bynajmniej nie był typowy wyłącznie dla dyskursu politycznego. Niestety, bardzo głęboko wniknął on w przestrzeń naukowej refleksji, zwłaszcza historycznej, socjologicznej, politologicznej, antropologicznej czy literaturoznawczej ${ }^{5}$. Wreszcie stał się, wraz z całym zestawem negatywnych stereotypów i uprzedzeń, częścią kultury popularnej, mającej jeszcze większą siłę oddziaływania. Tym samym Związek Radziecki jako niekwestionowany hegemon Europy Wschodniej zyskiwał niejako zewnętrzną (zachodnią) legitymizację swego panowania, albowiem w mocno upraszczających zachodnich wyobrażeniach Wschodu (Orientu) Moskwa stanowiła jedyne realne centrum polityczne zdolne do zapanowania nad rzekomym chaosem, nieustannymi waśniami etnicznymi czy innymi antagonizmami występującymi między etnosami Europy Wschodniej. Ubolewał nad tym zresztą Milan Kundera, uważany za jednego na największych propagatorów idei Europy Środkowej, pisząc, że prawdziwą tragedią Europy Środkowej nie jest Rosja czy Związek Radziecki, ale Europa Zachodnia, dla której to, iż Polacy, Czesi i Węgrzy potrafili przeciwstawić się niedemokratycznym reżimom w imię wartości charakterystycznych dla kultury Zachodu, było zupełnie obojętne. Największym problemem, zdaniem Kundery, było to, że Zachód nie zauważył nawet „zniknięcia” swojej integralnej części, jaką jest Europa Środkowa ${ }^{6}$.

W tym właśnie kontekście należy widzieć proces kształtowania idei Europy Środkowej w ostatnich dwóch dekadach panowania reżimów komunistycznych. Idea Europy Środkowej była przede wszystkim wyrazem braku zgody na próby odłączenia Polaków, Czechów, Słowaków oraz Węgrów (czasem wspominano także o Litwinach, Słoweńcach i Chorwatach) od ich cywilizacyjnego matecznika. Była ona w pierwszej kolejności dziełem ludzi kultury (pisarzy, poetów, dramaturgów) oraz nauki (głównie historyków i socjologów). O Europie Środkowej zaczęło

4 D. Skórczewski, Polska skolonizowana, Polska zorientalizowana. Teoria postkolonialna wobec „innej Europy”, „Porównania” 2009, nr 6, s. 96.

${ }_{5}$ Pisze o tym m.in. Will Kymlicka, obnażając w swoich książkach i artykułach stereotypy i przesądy rozpowszechnione w naukach społecznych na temat Europy Środkowo-Wschodniej. Zob. np. eadem, Nation-building and minority rights: Comparing West and East, „Journal of Ethnic and Migration Studies" 2000, nr 2, s. 183-212.

6 M. Kundera, Zachód porwany albo tragedia Europy Środkowej, „Zeszyty Literackie” 1984, nr 5, s. 20. 
się mówić już w latach 70. XX w. przy kawiarnianych stolikach, na kanwie różnych imprez kulturalnych, na seminariach naukowych, na tajnych dysydenckich spotkaniach. Pomimo rozmaitych restrykcji związanych z podróżami zagranicznymi intensyfikowały się wówczas więzi między polskimi, czeskimi, słowackimi i węgierskimi dysydentami, ludźmi otwarcie kontestującymi zadekretowany w Jałcie porządek geopolityczny i domagającymi się liberalizacji życia społecznego. Był to czas, w którym Václav Havel w znakomitym eseju zatytułowanym Siła bezsilnych w swej diagnozie reżimu totalitarnego trafia w samo sedno, stawiając tezę, że jego istotą jest oparcie się na kłamstwie. Jego zdaniem jedynie poprzez życie w prawdzie możliwa jest prawdziwa przemiana życia społecznego ${ }^{7}$. To motto zdawało się najsilniej oddziaływać na działania opozycji antykomunistycznej w państwach Europy Środkowej, prowadząc ostatecznie do zwycięstwa w 1989 r.

Sporo napisano już o samej idei Europy Środkowej w omawianym okresie. Nie ma więc sensu rozbieranie na czynniki pierwsze środkowoeuropejskiego dyskursu i wskazywanie jego najistotniejszych aspektów. Pozostańmy zatem przy stwierdzeniu, że do 1989 r. Europa Środkowa stanowiła niemal wyłącznie pojęcie historyczno-kulturowe bez jakichkolwiek poważniejszych ambicji przekuwania idei środkowoeuropejskiej w konkretny projekt polityczny. Andrzej Krasiński w ramach dysydenckiej dyskusji na temat Europy Środkowej stwierdza wprost, że „Europa Środkowa [jest] pojęciem, które głównie, jeśli nie wyłącznie, odnosi się do sfery świadomości, do sfery kultury"8. Można powiedzieć, że w pewnym sensie poprzestanie na analizie kulturowych aspektów środkowoeuropejskości stanowiło wyraz ostrożności, gdyż jej polityzacja mogła ożywić stare antagonizmy, których nie brakowało przecież we wzajemnych relacjach: polsko-czeskich, litewsko-polskich, słowacko-węgierskich czy czesko-słowackich. Wydaje się zatem, że świadomie unikano polityki w dyskursie środkowoeuropejskim, choć zapewne zdawano sobie sprawę, że podkreślanie wspólnoty wartości, odwoływanie się do wspólnej spuścizny kulturowo-cywilizacyjnej czy nieskrywana fascynacja twórczością kulturalną sąsiednich narodów - że to wszystko może stworzyć odpowiedni grunt pod przyszłą integrację polityczną.

\section{Polityczna instytucjonalizacja Europy środkowej}

Wraz z upadkiem komunizmu dyskurs środkowoeuropejski wszedł w zupełnie nowy etap z co najmniej dwóch względów. Po pierwsze, kluczowe stanowiska w polityce i mediach masowych w Polsce, Czechosłowacji i na Węgrzech objęli ludzie, którzy otwarcie deklarowali swoją sympatię do innych narodów tworzą-

7 Zob. V. Havel, Siła bezsilnych, [w:] Hrabal, Kundera, Havel... antologia czeskiego eseju, oprac. J. Baluch, Kraków 2001, s. 67-153.

8 A. Krasiński, Wprowadzenie, [w:] Między Wschodem i Zachodem, konwersatorium „Polska w Europie", Warszawa 1988, s. 4. 
cych Europę Środkową. Po drugie, początek lat 90. ubiegłego wieku cechował się dużą niestabilnością i poważnymi wstrząsami politycznymi w regionie wyzwalającej się spod hegemonii ZSRR, a ściślej - Rosji, Europy Wschodniej. Rozpadał się Związek Radziecki, na Bałkanach wybuchały kolejne wojny zbierające krwawe żniwo, a w Bułgarii, zwłaszcza w Rumunii, miały miejsce poważne niepokoje społeczne mogące zaważyć na kierunku zmian politycznych i uniemożliwić lub znacząco opóźnić demokratyczną transformację. Jedynym miejscem, które wydawało się stanowić oazę względnego spokoju, były trzy, a od 1993 r. cztery, państwa Europy Środkowej (Polska, Republika Czeska, Słowacja i Węgry), mimo że stosunki czesko-słowackie i węgiersko-słowackie z początku lat 90 . bynajmniej nie należały do przyjaznych.

Obydwa te czynniki spowodowały, że możliwe stało się polityczne zinstytucjonalizowanie Europy Środkowej poprzez powołanie do życia w 1991 r. Grupy Wyszehradzkiej (V4) w węgierskiej miejscowości Visegrád. Poza oficjalnie deklarowanymi celami, wśród których były m.in. intensyfikacja współpracy w różnych obszarach stosunków międzynarodowych oraz integracja ze strukturami euroatlantyckimi (EWG i NATO) ${ }^{9}$, przywódcom politycznym przyświecał także bardzo ważny cel wizerunkowy. Chodziło mianowicie o to, by cztery środkowoeuropejskie państwa nie były dłużej uznawane za integralną część Europy Wschodniej. Innymi słowy, chodziło o zręczne przesunięcie wspomnianej granicy cywilizacyjnej będącej produktem orientalistycznego dyskursu, a tym samym uniknięcie dalszej stygmatyzacji i włączenie do zachodnioeuropejskiego kręgu kulturowego i politycznego ${ }^{10}$. Do pewnego stopnia udało się ten cel osiągnąć, ale tylko w takim sensie, że kraje wyszehradzkie rozpoznawane są na Zachodzie jako jakościowo odmienne od pozostałych państw regionu - zwłaszcza tych postradzieckich. Nie oznacza to jednak, że powszechnie uznaje się je za równorzędnych partnerów państw zachodnich, o czym świadczy wiele przykładów protekcjonalnego traktowania państw tego regionu przez liderów takich państw Zachodu, jak Francja, Niemcy czy Wielka Brytania.

Grupa Wyszehradzka została powołana do życia głównie jako forum koordynacji polityk zagranicznych Polski, Czechosłowacji (od 1993 r. - Republiki Czeskiej i Słowacji) oraz Węgier. Jej celem było doprowadzenie do jak najszybszego członkostwa wymienionych państw w Unii Europejskiej oraz NATO. W zasadzie od samego początku współpraca ta szwankowała, a to za sprawą bardzo złych stosunków węgiersko-słowackich w latach 90. ubiegłego wieku oraz w latach 20012002 (sprawa tzw. karty Węgra i dekretów Beneša), pewnego ostracyzmu wobec Słowacji w okresie rządów Vladimíra Mečiara (głównie w latach 1994-1998) czy

9 Zob. Deklaracja Wyszehradzka 1991, http://www.visegradgroup.eu/documents/visegrad-declarations/visegrad-declaration-110412-2 (dostęp: 18 stycznia 2017).

10 R. Zenderowski, Europa Środkowa jako „ucieczka przed Wschodem” czy „pomost” między Wschodem i Zachodem?, [w:] Europa Środkowa: wspólnota czy zbiorowość?, red. R. Zenderowski, Wrocław-Warszawa-Kraków 2004, s. 36-48. 
Węgier w okresie drugich rządów Victora Orbana (od 2010), lecz także nieskrywanej niechęci Václava Klausa jako premiera (1993-1997), a następnie prezydenta Republiki Czeskiej (2003-2013) do współpracy w ramach V4. Do tego dochodziły obawy, zwłaszcza Republiki Czeskiej i Słowacji, dotyczące tego, że wskutek intensyfikacji współpracy Polska jako największe państwo w grupie, liczące więcej mieszkańców niż trzy pozostałe państwa łącznie i przewyższające ich zsumowany $\mathrm{PKB}$, zechce uzyskać status regionalnego hegemona, jakby nie dostrzegając, że tego rodzaju ambicje miały od początku lat 90. XX w. Niemcy umiejętnie prowadzące swoją politykę zagraniczną w regionie Europy Środkowo-Wschodniej.

Tymczasem państwa V4 stanowią w grupie jedenastu członków UE, czyli tzw. nowej Unii, jej rdzeń. Są to państwa o zbliżonych tradycjach w zakresie kultury politycznej, będące na podobnym poziomie rozwoju gospodarczego, postrzegane na zewnątrz jako awangarda demokracji i ruchów antytotalitarnych. Pozostałe państwa tzw. nowej Unii wydają się akceptować przywództwo V4 w grupie. Jednocześnie nie sposób jednak nie zauważyć ewidentnych różnic występujących między czterema państwami, które w znaczącym stopniu osłabiają wewnętrzną spoistość Grupy Wyszehradzkiej. Do zasadniczych i najważniejszych różnic oddziałujących zarówno na politykę zagraniczną, jak i na opinię publiczną państw środkowoeuropejskich w odniesieniu do spraw międzynarodowych należy zaliczyć:

\section{Czasową „rozległość” tradycji państwowych}

Czesi pozbawieni byli suwerennej państwowości przez 298 lat (1620-1918 — jeśli uznać Czechosłowację za państwo, w którym naród czeski posiadał podmiotowość polityczną). Słowacy uzyskali ją w zasadzie dopiero w 1993 r. (jeśli nie liczyć wojennego Państwa Słowackiego). Węgrzy pozbawieni byli suwerenności przez 341 lat (jeśli uznać, że utworzenie Austro-Węgier w 1867 r. oznaczało autonomię polityczną). Z kolei Polacy nie posiadali własnego państwa jedynie przez 123 lata, czyli najkrócej ze wszystkich narodów Europy Środkowo-Wschodniej, włącznie z Rosjanami.

\section{Doświadczenia mocarstwowe lub ich brak}

W regionie Europy Środkowo-Wschodniej doświadczenia takie były udziałem Polski, Węgier, Rosji, Austrii i Turcji. Natomiast Czesi, mimo że w średniowieczu tworzyli liczące się w regionie państwo, nigdy takiego statusu nie osiągnęli, Słowacy zaś suwerenność uzyskali dwie dekady temu. Powoływanie się przez Słowaków i Czechów na tradycję Wielkich Moraw ma w sobie więcej z pansłowiańskiego dziewiętnastowiecznego romantyzmu niż chłodnej kalkulacji geopolitycznej.

\section{Odmienny charakter relacji z dwiema potęgami regionalnymi - Rosją i Niemcami}

Polacy mają jednoznacznie negatywny bilans stosunków z Rosją, zwłaszcza w odniesieniu do XIX i XX w. W wypadku Niemiec, jeśli spojrzeć przez pryzmat ponadtysiącletniej historii, przedstawia się on ambiwalentnie. Negatywne piętno odcisnął zwłaszcza okres okupacji nazistowskiej, a jednocześnie stosunki kulturalne, gospodarcze i polityczne z państwami niemieckimi okresu późnego średnio- 
wiecza i czasów nowożytnych (do rozbiorów) można postrzegać w pozytywnych kategoriach. Z kolei czeskie i słowackie doświadczenia polityczne z Rosją są raczej znikome i w zasadzie ograniczają się do drugiej połowy XX w., przy czym w XIX w. - w odróżnieniu od ziem polskich - na ziemiach tych bujnie rozwijał się ruch panslawistyczny pod nieskrywanym patronatem rosyjskim. W Czechach, lecz przede wszystkim na Słowacji, nie brakowało zatem tendencji rusofilskich wśród przedstawicieli elit politycznych i kulturalnych. Czeskie i słowackie doświadczenia z Niemcami są bardziej skomplikowane z uwagi na tradycje wielowiekowego współżycia tych narodów, w którym bez trudu można wskazać zarówno jasne, jak i ciemne strony. Pięknie to swego czasu ujął V. Havel, pisząc, że „Niemcy są naszą inspiracją i naszym bólem, źródłem wielu uprzedzeń i punktem odniesienia. Poprzez stosunek do Niemców Czesi nie tylko sami siebie definiują politycznie i filozoficznie, ale określają także swój stosunek do własnej historii"11. Z kolei Węgrzy mają bardzo bogate i ambiwalentne doświadczenia z Niemcami, którzy uczestniczyli przecież (Habsburgowie) w rozbiorze państwa węgierskiego, przeciwko którym zbuntowali się w latach 1848/1849, a rewolucja ta została krwawo stłumiona z pomocą Rosjan, ale z którymi od 1867 r. współtworzyli państwo i z którymi byli w sojuszu politycznym i militarnym w czasie I i II wojny światowej. Natomiast z Rosjanami Węgrzy nie mieli intensywnych kontaktów, przy czym dwie daty ewidentnie zaważyły na negatywnym stosunku do Rosji: 1849 (krwawe stłumienie rewolucji węgierskiej) i 1956 (powstanie budapeszteńskie).

\section{Doświadczenia odnoszące się do wieloetniczności i wielokulturowości}

Wszystkie cztery narody mają w swojej historii takowe doświadczenia, choć istnieją w tym względzie pewne różnice. Otóż o ile Czesi i Słowacy przez długi czas nie mieli statusu narodu dominującego, przeciwnie - byli politycznie podporządkowani Niemcom i Węgrom, o tyle Polakom i Węgrom takowe doświadczenia nie były obce. W 1660 r. katolicy (w domyśle głównie Polacy, lecz także Litwini i częściowo Niemcy oraz Ormianie) stanowili raptem ok. 45\% całej populacji, zaś w 1772 r. - 43\% ludności Rzeczypospolitej Obojga Narodów. Bardzo podobnie przedstawiał się odsetek Węgrów w Koronie Św. Stefana. Szacuje się, że pod koniec XVIII w. Węgrzy stanowili zaledwie ok. 30\% mieszkańców Królestwa, a w 1842 r. - 37\%. Niemniej, Polacy i Węgrzy dominowali politycznie nad pozostałą ludnością o różnej przynależności etnicznej i konfesyjnej ${ }^{12}$.

\section{Odmienne postrzeganie innych narodów}

Czesi i Polacy postrzegają się zasadniczo pozytywnie. Czesi są na drugim miejscu w rankingu najbardziej lubianych przez Polaków narodów - 50\% (za Włochami). Z kolei Polska w 2015 r. uplasowała się w tożsamym rankingu na dwunastej

11 A. Grajewski, Trudne pojednanie. Stosunki czesko-niemieckie 1989-1999, Warszawa 2000, s. 50.

12 M. Velikonja, Slovenian and Polish religio-national mythologies: A comparative analysis, „Religion, State \& Society” 2003, nr 3, s. 253, 833; H. Wereszycki, Pod berłem Habsburgów. Zagadnienia narodowościowe, Kraków 1986, s. 78, 149; J. Chlebowczyk, Procesy narodowotwórcze we wschodniej Europie środkowej w dobie kapitalizmu, Warszawa-Kraków 1975, s. 118. 
pozycji, przy czym z podobnym odsetkiem osób deklarujących sympatię - 53\%. Zarówno Polacy (48\%), jak i Czesi (90\%) deklarują sympatię do Słowaków lub Słowacji. W gronie najbardziej nielubianych narodów w Polsce znaleźli się Rosjanie (druga pozycja - 50\%) oraz Ukraińcy (szóste miejsce - 32\%). Dla porównania: Czesi - 14\%, Słowacy - 12\%. W wypadku Republiki Czeskiej Rosja uplasowała się na szóstej pozycji (43\%), a na dziewiątej znalazła się Ukraina (32\%). Dla porównania: Polska - 13\%, Słowacja - tylko $1 \%$. Niestety nie udało mi się dotrzeć do wyników badań słowackiej opinii publicznej dotyczących stosunku do innych narodów. W 2014 r. przeprowadzono jednak badania, w których zapytano mieszkańców Słowacji o to, który kraj jest im najbliższy (najbardziej podobny pod względem kulturowym). Na pierwszym miejscu uplasowała się Republika Czeska (75\%), na drugim - Polska (12\%). Do państw zagrażających Słowacji zaliczono przede wszystkim Rosję (24\%) i Ukrainę (22\%). Węgry, na które w 1996 r. wskazało aż 40\% respondentów, straciły w oczach Słowaków swój wrogi potencjał, ponieważ w 2014 r. ten kraj podało raptem 5\% mieszkańców Słowacji ${ }^{13}$. Jeśli chodzi o percepcję innych narodów przez Węgrów, na pierwszym miejscu rankingu najbardziej lubianych państw znajduje się Austria (93\%). Polska uplasowała się na siódmej pozycji (77\%), Republika Czeska — na miejscu dziewiątym (66\%), Słowacja zaś - na dziesiątym $(59 \%)^{14}$.

\section{Współpraca polityczna po 2004 r.}

Punktem krytycznym dla Grupy Wyszehradzkiej wydaje się rok 2004, w którym to osiągnięte zostały dwa główne cele Grupy, a mianowicie przystąpienie do UE i NATO. Rozpoczął się wówczas całkowicie nowy etap współpracy politycznej państw środkowoeuropejskich. Jej celem miało być wzmocnienie regionalnego porozumienia w obrębie Unii Europejskiej (na podobieństwo regionalnego porozumienia państw skandynawskich czy śródziemnomorskich). Koordynacja polityk w postaci narad przywódców państw wyszehradzkich przed posiedzeniami Rady Europejskiej od początku bazowała na dość optymistycznym założeniu, że istnieje lub może istnieć wspólnota interesów w odniesieniu do konkretnych kwestii politycznych lub gospodarczych. I choć w wielu wypadkach udawało się osiągnąć porozumienie (np. w odniesieniu do redukcji emisji gazów cieplarnianych po 2020 r.), to niestety nie wypracowano dostatecznie efektywnych i trwałych mechanizmów współpracy regionalnej i sektorowej wewnątrz UE.

13 Sympatie ceské verejnosti k nekterým zemím - leden 2015, Centrum pro výzkum verejného mínení, 20. února 2015, https://cvvm.soc.cas.cz (dostęp: 18 stycznia 2017); Stosunek do innych narodów, CBOS nr 14/2015, www.cbos.pl (dostęp: 18 stycznia 2017); M. Bahna, Krajiny kultúrne najpodobnejšie a krajiny pre Slovensko nebezpečné. Čo sa zmenilo v období 1996-2014?, Sociologický ústav SAV, http://www.sociologia.sav.sk/cms/uploaded/2172_attach_1_krajiny_podobne_a_krajiny_nebezpecne.pdf (dostęp: 18 stycznia 2017).

\footnotetext{
14 Psyma Hungary 2013.
} 
O ile rok 2004 postawił przed przywódcami politycznymi pytanie o sens lub obszary i mechanizmy współpracy w ramach Unii Europejskiej oraz NATO, o tyle dekadę później, w roku 2014, państwa tego regionu stanęły przed bardzo ważnym pytaniem o to, w jaki sposób odpowiedzieć na agresję Rosji na Ukrainę oraz jak ustosunkować się do przemian politycznych na Ukrainie zapoczątkowanych przez Majdan. W dużej mierze dylematy te związane są ze stosunkiem państw wyszehradzkich do projektu i realizacji Partnerstwa Wschodniego jako ważnego elementu Europejskiej Polityki Sąsiedztwa. Wydaje się, że obydwie te kwestie (w powiązaniu z innymi, o których będzie jeszcze mowa) mogą zadecydować o przyszłości Grupy Wyszehradzkiej, jej integralności i skuteczności oddziaływania w polityce międzynarodowej.

Rosji, prowadzącej umiejętną grę na różnych polach i wymiarach polityki międzynarodowej, udało się nie tylko poróżnić członków Grupy Wyszehradzkiej, lecz także doprowadzić do poważnych kontrowersji i rozdźwięków w polityce zagranicznej i wewnętrznej w obrębie elit politycznych w państwach wyszehradzkich. „Konflikt na Ukrainie spowodował wyraźny rozłam w grupie, którą utworzono, by uczynić lepiej słyszalnym głos czterech krajów Europy Środkowej. W związku ze swym zdecydowanym stanowiskiem wobec Rosji Polska jest w niej outsiderem"15. Jednoznacznie proukraińskie i antyrosyjskie stanowisko Polski stało się kłopotliwe dla Pragi, Bratysławy i Budapesztu, które starają się niuansować swoją politykę zagraniczną, kładąc większy nacisk na podtrzymanie, na ile to możliwe, współpracy gospodarczej z Rosją, która ma istotne znaczenie dla gospodarek naszych sąsiadów. Trzeba także pamiętać, że Czesi, Słowacy i Węgrzy, nie licząc pewnych negatywnych epizodów (takich jak powstania węgierskie 1848/1849 i 1956 r. krwawo stłumione przez Rosjan czy Praska Wiosna 1968 spacyfikowana przez czołgi radzieckie), w swej historii nie mieli tak jednoznacznie negatywnych i długotrwałych stosunków z Rosją, dlatego też trudno im podzielać obawy Warszawy dotyczące imperialnej polityki Rosji.

Wspomniane głębokie rozdźwięki w odniesieniu do polityki zagranicznej wobec Rosji w obrębie sceny politycznej poszczególnych państw dotyczą szczególnie Republiki Czeskiej i Słowacji.

$\mathrm{Na}$ początku 2015 r. trzy ministerstwa czeskiego rządu przygotowały dokumenty, które w zasadniczo różny sposób definiują czeską politykę zagraniczną wobec Moskwy.

Ministerstwa spraw zagranicznych i obrony traktują Rosję jako kraj destabilizujący europejską architekturę bezpieczeństwa, dążący do rewizji porządku międzynarodowego. Z kolei minister przemysłu i handlu traktuje Rosję jako kluczowego pozaunijnego partnera gospodarczego Czech, z którym należy zacieśniać współpracę. Rządowy dwugłos w sprawie Rosji ma odzwierciedlenie w działaniach lewicowe-

15 Wojna na Ukrainie i działania Rosji dzielą Grupę Wyszehradzką, http://www.money.pl/gospodarka/unia-europejska/wiadomosci/artykul/wojna-na-ukrainie-i-dzialania-rosji-dziela,189,0,1741245. html (dostęp: 18 maja 2015). 
go premiera Bohuslava Sobotki, który z jednej strony ze zrozumieniem przyjmuje udział prezydenta Miloša Zemana w moskiewskich uroczystościach z okazji 70. rocznicy zwycięstwa, z drugiej strony na przykład blokuje posiedzenie czesko-rosyjskiej międzyrządowej komisji gospodarczej ${ }^{16}$.

Co ciekawe, „pomimo jednoznacznego stanowiska wobec rosyjskich działań na Ukrainie nawet najwięksi czescy krytycy Rosji unikają retoryki »odstraszania« Rosji przez NATO"17. Czescy politycy zapewniają jednocześnie, że rozumieją obawy Polski czy państw bałtyckich, ale chętniej niż o konkretnych deklaracjach dotyczących udziału Republiki Czeskiej we wzmacnianiu potencjału militarnego NATO mówi się o „zwiększaniu poczucia bezpieczeństwa”. Wyraźna jest przy tym niechęć Czechów do zakładania nowych baz NATO z udziałem zachodnich sojuszników na wschodniej flance Sojuszu ${ }^{18}$.

W wypadku Słowacji również występują dysharmonie pomiędzy podejściem prezydenta a podstawą premiera Słowacji, przy czym dotyczą one samej istoty konfliktu rosyjsko-ukraińskiego.

O ile prezydent Kiska nie ma wątpliwości, że na wschodzie Ukrainy walczą rosyjscy żołnierze przeciwko siłom ukraińskim, o tyle premier Fico sytuację interpretuje jako geopolityczny konflikt między USA i Rosją. W jego opinii na skutek tego, że UE włączyła się w ten konflikt, cierpi wiele małych krajów UE, w tym Słowacja ${ }^{19}$.

Robert Fico otwarcie kontestuje sankcje ekonomiczne i polityczne wobec Rosji, uznając je za kontrproduktywne i prowadzące do niepotrzebnej eskalacji napięcia. Jednocześnie Słowacja nie blokuje sankcji, jako że są one popierane przez większość państw UE, ale stara się ograniczać ich zakres. R. Fico, który apeluje o „otwarty i intensywny dialog z Rosją," zajmuje zdecydowanie odmienne od prezydenta Andreja Kiski stanowisko w kwestii polityki obronnej. Prezydent Słowacji na szczycie NATO w Newport zaoferował utworzenie centrum logistycznego w Popradzie, a ponadto zapowiedział wzmocnienie słowackiej obecności w dowództwie w Szczecinie, zachęcając jednocześnie sojuszników do ćwiczeń na słowackich poligonach. Publicznie przyjął również zobowiązanie, że do 2020 r. Słowacja zwiększy budżet obronny z $1,04 \%$ do poziomu $1,6 \% \mathrm{PKB}$, co potwierdził minister obrony. Co ciekawe, po szczycie zobowiązanie to zostało zakwestionowane przez premiera R. Ficę, który jest przeciwny zarówno zwiększaniu wydatków na obronę, jak i stałej obecności dodatkowych sił NATO na Słowacji, przy czym jego zdanie w tej kwestii ma charakter decydujący ${ }^{20}$.

16 J. Groszkowski, Czeskie dylematy wobec Rosji i NATO, http://www.osw.waw.pl/pl/publikacje/ analizy/2015-04-01/czeskie-dylematy-wobec-rosji-i-nato (dostęp: 18 maja 2015).

17 Ibidem.

18 Ibidem.

19 M. Gniazdowski, J. Groszkowski, A. Sadecki, Wyszehradzka kakofonia wobeckonfliktu rosyjsko-ukraińskiego, http://www.osw.waw.pl/pl/publikacje/analizy/2014-09-10/wyszehradzka-kakofoniawobec-konfliktu-rosyjsko-ukrainskiego (dostęp: 18 maja 2015).

20 Ibidem. 
W Polsce główne siły polityczne (PO, PiS) przynajmniej w warstwie werbalnej opowiadają się dość jednoznacznie po stronie ukraińskiej, zdecydowanie sprzeciwiając się rosyjskiej agresji. Niemniej jednak, od pewnego czasu podsycane są nastroje antyukraińskie (np. poprzez przypominanie o ludobójstwie na Wołyniu, wskazywanie na neofaszystowskie tendencje na Ukrainie, ukraińską politykę historyczną gloryfikującą postaci kojarzone ze skrajnie antypolskimi działaniami), a także antyamerykańskie, co można uznać za proces pożądany przez Moskwę. Niewiele wskazuje na to, by polska dyplomacja starała się wypracować ze stroną czeską i słowacką wspólne stanowisko. Konsultacje prowadzone są raczej na linii Warszawa-Berlin i Warszawa-Waszyngton, co w obliczu chłodnych relacji amerykańsko-niemieckich, przy jednoczesnym braku alternatywnych rozwiązań dyplomatycznych, należy uznać za bardzo ryzykowną grę. Ponadto istotne znaczenie może mieć fakt, że Rosja zręcznie rozgrywa „kartę smoleńską", skutecznie antagonizując główne siły polityczne w naszym kraju.

Na Węgrzech, podobnie jak w Polsce, panuje pewien konsensus w odniesieniu do polityki zagranicznej względem Moskwy i konfliktu rosyjsko-ukraińskiego. Politycy na ogół unikają jednoznacznych stwierdzeń, aby nie narazić się na krytykę ze strony Moskwy i Brukseli. Trzeba także pamiętać, że V. Orban sporo zainwestował w zacieśnienie współpracy z Rosją, a ochłodzenie na linii UE-Rosja stawia pod znakiem zapytania realizację rosyjsko-węgierskich przedsięwzięć gospodarczych i energetycznych. W odróżnieniu zwłaszcza od Polski rząd węgierski kwestionuje sensowność sankcji nałożonych na Rosję. Jednocześnie V. Orban otwarcie deklaruje podwyższenie wydatków na armię i zbrojenia (z 0,8\% do 1,39 PKB w 2022 r.) oraz popiera obecność wojsk NATO, w tym rozbudowę bazy lotnictwa NATO w Pápa. Ponadto rząd węgierski zapowiedział wysłanie żołnierzy na ćwiczenia NATO w państwach bałtyckich, udział w „szpicy” NATO oraz wyasygnowanie dodatkowych środków na bezpieczeństwo cybernetyczne ${ }^{21}$.

Reasumując, należy stwierdzić, że rządy Republiki Czeskiej i Słowacji, jakkolwiek formalnie przyłączają się do większości unijnej w kwestii postrzegania konfliktu ukraińsko-rosyjskiego i potępiają działania Moskwy, w rzeczywistości wysyłają wiele sprzecznych sygnałów, dając do zrozumienia, że zależy im na utrzymaniu dobrych stosunków z Moskwą, czego najlepszym wyrazem jest obecność 9 maja w Moskwie prezydenta Republiki Czeskiej i premiera Słowacji, którzy postanowili jednak nie brać udziału w samej defiladzie zwycięstwa, aby uniknąć silnej krytyki ze strony UE. Polityka tych państw względem NATO jest przy tym zasadniczo odmienna od polityki Warszawy i Budapesztu. Rząd węgierski, podobnie jak czeski i słowacki, niechętnie, ale uczestniczy w sankcjach UE, deklarując jednocześnie sojuszniczą solidarność w NATO, zwiększając budżet obronny i deklarując poparcie dla utworzenia baz NATO na swoim terytorium. Stanowisko Warszawy jest zatem skrajnie odmienne od podejścia Pragi i Bratysławy i różni się zasadniczo od polityki Budapesztu w odniesieniu do kwestii sankcji.

21 Ibidem. 


\section{Środkowoeuropejskie alternatywy dla Grupy Wyszehradzkiej?}

W konsekwencji narastających rozbieżności w styczniu 2015 r. na horyzoncie pojawiła się poważna alternatywa dla Grupy Wyszehradzkiej — „Trójkąt Sławkowski” - polityczna inicjatywa związana z tzw. deklaracją ze Sławkowa (niem. Austerlitz, Republika Czeska). Trzy kraje - Austria, Republika Czeska i Słowacja - podpisały tam porozumienie, które stawia sobie ambitny cel bycia „platformą współpracy w zakresie infrastruktury i transportu, bezpieczeństwa energetycznego, relacji transgranicznych, zatrudnienia młodzieży, społecznego wymiaru integracji europejskiej oraz kontaktów z krajami sąsiadującymi z UE”22. Z inicjatywą utworzenia „trójkąta” wystąpiły władze czeskie, którym zależy na ściślejszej współpracy z Austrią będącą liderem gospodarczym regionu. Do współpracy zdecydowała się dołączyć Bratysława. Można postawić tezę, że Republika Czeska i Słowacja dały tym samym innym państwom do zrozumienia, że porozumienie wyszehradzkie nie jest na miarę ich oczekiwań i nie rokuje wyjścia z kryzysu, w którym się znalazło.

Jakub Groszkowski, analityk Ośrodka Studiów Wschodnich, słusznie zauważa, że

choć dla czeskich władz, które inicjowały ten format, główną przesłanką było wzmocnienie współpracy stricte regionalnej, [...] gremium to Austria i Słowacja zaczęły wykorzystywać także do krytyki sankcji i promocji ugodowego podejścia UE w stosunkach z Rosją ${ }^{23}$.

Zapowiadane regularne konsultacje przedstawicieli trzech państw przed posiedzeniami Rady Europejskiej, mimo formalnych deklaracji, że nie są one wymierzone w integralność Grupy Wyszehradzkiej, z całą pewnością będą służyć marginalizacji Polski jako największego członka V4, mającego zasadniczo odmienne zdanie w kwestii konfliktu rosyjsko-ukraińskiego oraz sankcji nałożonych na Rosję. Nie jest to w dodatku jedyna różnica interesów. O ile bowiem Polska popiera i intensywnie działa na rzecz promocji Partnerstwa Wschodniego, robiąc dobrą minę do złej gry, o tyle państwa skupione w „trójkącie sławkowskim” (do którego niewykluczone, że dołączą Węgry) z racji silnych więzi historycznych, lecz także interesów strategicznych, zdecydowanie bardziej zorientowane są na region bałkański i wspierają aspiracje Serbii do członkostwa w UE.

Wydaje się, że rząd austriacki, który od kilku dekad myśli i działa na rzecz odtworzenia politycznych i społeczno-ekonomicznych więzi ukształtowanych w okresie monarchii habsburskiej, wykorzystał idealny moment na odciągnięcie od Wyszehradu naszych południowych sąsiadów (kwestią czasu wydaje się członkostwo

22 M. Palade, Uśmierciliśmy Grupę Wyszehradzką, http://www.mysl-polska.pl/node/372 (dostęp: 20 maja 2018).

23 J. Groszkowski, Deklaracja sławkowska. Nowy format współpracy regionalnej, http://www.osw. waw.pl/pl/publikacje/analizy/2015-02-04/deklaracja-slawkowska-nowy-format-wspolpracy-regionalnej (dostęp: 18 maja 2015). 
Węgier w tym projekcie, który ma duże szanse powodzenia; niewykluczone, że również Słowenia będzie dążyć do integracji z grupą sławkowską).

Zdaje się, że co najmniej trzy rzeczy przesądziły o głębokiej zapaści w stosunkach między Warszawą z jednej strony, a z drugiej — pozostałymi państwami wyszehradzkimi. Po pierwsze, chodzi o fiasko Partnerstwa Wschodniego, projektu, w stosunku do którego Praga, Bratysława i Budapeszt nie wykazywały większego entuzjazmu, choć formalnie go popierały ${ }^{24}$. Jego niepowodzenie osłabiło Polskę jako potencjalnego lidera $\mathrm{w}$ regionie. Po drugie, jednoznacznie antyrosyjskie stanowisko Polski zostało uznane przez pozostałe państwa V4 za zbyt ryzykowne w sytuacji i tak już mocno zagrożonych relacji gospodarczych z Moskwą. Zdystansowanie się wobec polityki Warszawy ze strony Pragi, Bratysławy i Budapesztu miało stanowić wyraz pragmatyzmu w polityce zagranicznej. I wreszcie, po trzecie, intensywna współpraca Warszawy i Berlina, której cele rzadko były konsultowane z pozostałymi państwami Grupy, stała się istotnym źródłem nieufności ze strony wyszehradzkich partnerów.

Coraz więcej wskazuje na to, że pogłębiająca się izolacja Polski w regionalnej polityce międzynarodowej - wyrażająca się przede wszystkim niewejściem Polski do tzw. czworokąta normandzkiego (Francja, Niemcy, Ukraina, Rosja), mającego na celu rozwiązanie kryzysu ukraińskiego; słabnącą rolą, by nie rzecz - dezintegracją Grupy Wyszehradzkiej; coraz bardziej marginalnym znaczeniem Trójkąta Weimarskiego, lecz także osłabieniem więzi z państwami bałtyckimi i fiaskiem w zakresie normalizacji stosunków z Białorusią - sprzyjać będzie przesunięciu się ośrodka współpracy międzynarodowej na południe, w stronę powstającego Trójkąta Sławkowskiego, oddziałującego politycznie i ekonomicznie na państwa tzw. Bałkanów Zachodnich i regionu Morza Czarnego, ale niespecjalnie zainteresowanego wymiarem wschodnim (zwłaszcza Białorusią i Ukrainą). Rzecz w tym, że w przestrzeni geopolitycznej, w jakiej znajduje się Polska, niemożliwe jest zachowanie suwerenności bez istotnego wsparcia ze strony południowych sąsiadów oraz Ukrainy. Innymi słowy, w naszych warunkach albo konsekwentnie realizuje się ambicje odgrywania roli mocarstwa regionalnego, albo traci się suwerenność. Tymczasem trudno mówić o wsparciu ze strony Ukrainy - państwa, które samo go potrzebuje; w dodatku na naszych oczach rozpada się Grupa Wyszehradzka. Obecna sytuacja Polski jest konsekwencją zarówno niezależnych od nas międzynarodowych procesów politycznych, jak i - w co najmniej w takim samym stopniu — stanowi efekt błędów w prowadzeniu polityki zagranicznej, którym należałoby poświęcić osobne opracowanie. Pytanie, kto najwięcej zyskuje na marginalizacji Polski, wydaje się pytaniem retorycznym.

Wracając do początku naszych rozważań dotyczących mitu Europy Środkowej, można powiedzieć, że bardzo dużo wskazuje na to, że idea środkowoeuropejskiej

${ }^{24}$ Grupa Wyszehradzka wspiera Partnerstwo Wschodnie, http://www.osw.waw.pl/pl/publikacje/ analizy/2011-06-29/grupa-wyszehradzka-wspiera-partnerstwo-wschodnie (dostęp: 19 maja 2015). 
wspólnoty narodów, której fundamentem obok pewnych podobieństwkulturowych była niezłomna walka i opór przeciwko komunistycznej opresji, znajduje się w poważnym kryzysie. Pewien porządek instytucjonalny zaprojektowany przez czołowych działaczy antykomunistycznej opozycji przestaje byćz wielu względów atrakcyjny. Idea ściślejszej współpracy czterech środkowoeuropejskich narodów, której patronowali Czesław Miłosz, Milan Kundera, Václav Havel czy György Konrád, nie jest już tak nośna i wyraźnie ustępuje miejsca idei Donauraum, stanowiącej próbę reintegracji społeczno-gospodarczej i kulturowo-cywilizacyjnej dawnej monarchii habsburskiej z rozszerzeniem na Bałkany (bez Grecji, Macedonii, Albanii i Kosowa) i Rumunię z Mołdawią (zob. rysunek 1) przy jednoczesnym zachowaniu politycznej autonomii państw tworzących to porozumienie (w czym do złudzenia przypomina niemiecką koncepcję Mitteleuropy). Koncepcja nowej Europy Środkowej (tym razem bez Polski), poza prawdopodobnym poparciem ze strony państw peryferyjnych UE (takich jak Rumunia czy Bułgaria) oraz części krajów bałkańskich żywo zainteresowanych modernizacją, może liczyć na poważne wsparcie ze strony Unii Europejskiej. W 2011 r. Rada Europejska zatwierdziła bowiem strategię UE dla regionu Dunaju (EUSDR). Jest ona drugą tego typu strategią makroregionalną po przyjętej w 2009 r. strategii dla regionu Morza Bałtyckiego (zob. rysunek 2) ${ }^{25}$. W odpowiedzi na tę integrację Polska teoretycznie mogłaby powrócić do idei jagiellońskiej, wzmacniając współpracę z Litwą (a może także z innymi państwami bałtyckimi), Białorusią i Ukrainą. Pytanie tylko, czy te państwa są nią obecnie zainteresowane? Niestety niewiele na to wskazuje.

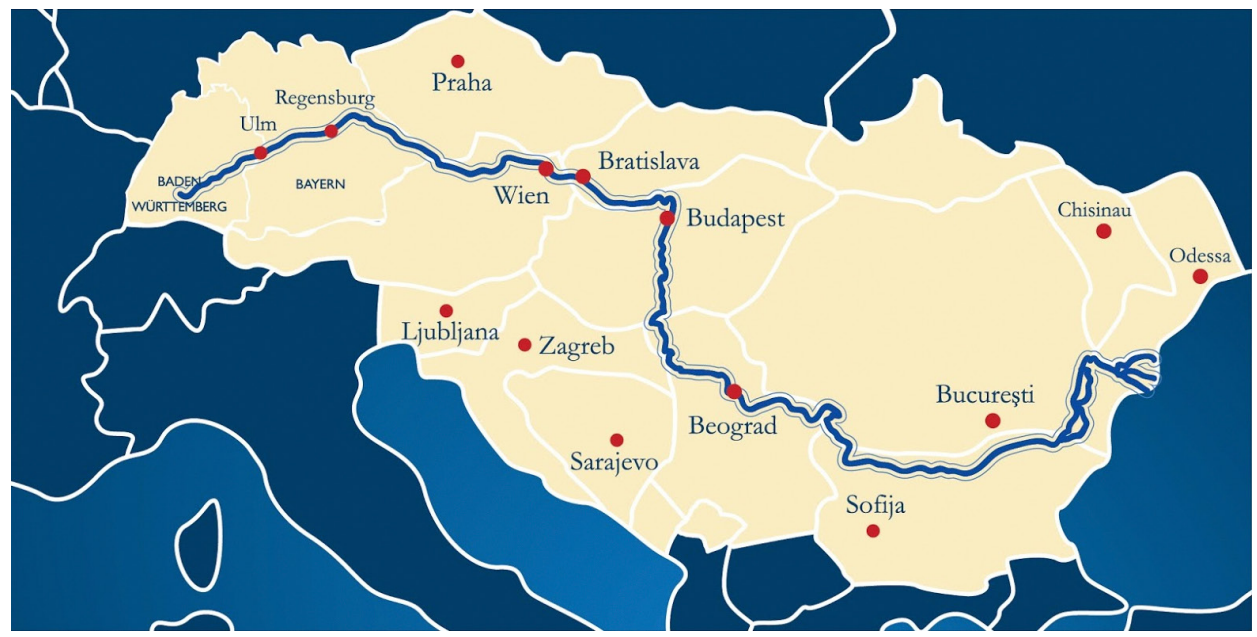

Rysunek 1. Donauraum

Źródło: http://www.interreg.de/INTERREG2014/DE/Interreg/SechsProgrammraeume/Donauraum/donauraumnode.html (dostęp: 6 maja 2018).

${ }^{25}$ M. Gniazdowski et al., Strategia Unii Europejskiej dla regionu Dunaju. Implikacje dla Polski i Grupy Wyszehradzkiej, Warszawa 2011, s. 5. 


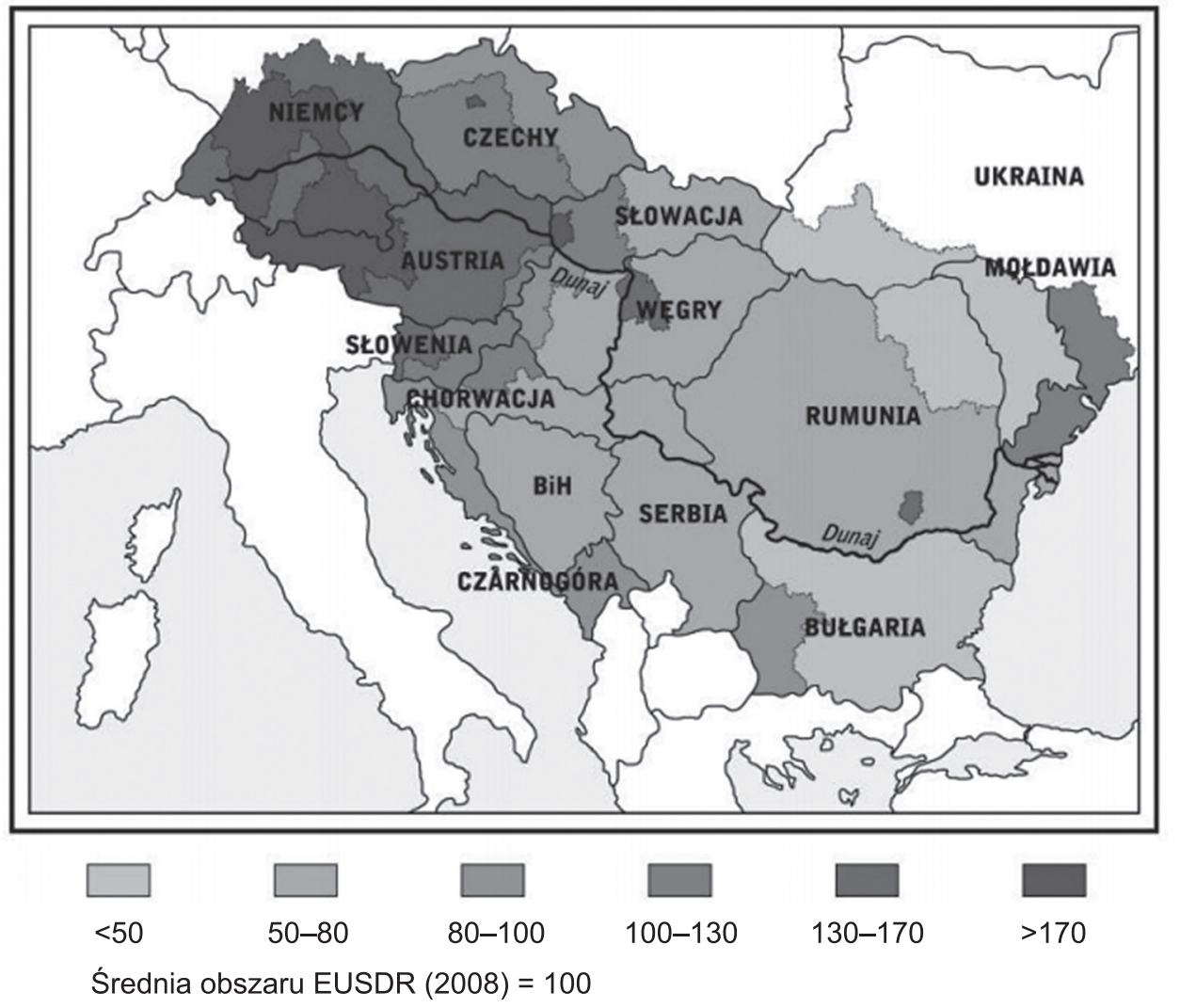

Rysunek 2. Zróżnicowanie zamożności regionów EUSDR (PKB per capita)

Źródło: M. Gniazdowski et al., Strategia Unii Europejskiej dla regionu Dunaju. Implikacje dla Polski i Grupy Wyszehradzkiej, Warszawa 2011, s. 117.

\section{Kryzys Grupy Wyszehradzkiej w kontekście wyzwań rozwojowych regionu}

Racje historyczne i polityczne popychające Czechów i Słowaków (a być może również pozostałe państwa naddunajskie) do pogłębiania współpracy z Austrią nie mogą przesłonić znaczącej nierównowagi pomiędzy uczestnikami tworzącego się Trójkąta Sławkowskiego. Przywoływane obawy partnerów Polski w Grupie Wyszehradzkiej, dotyczące jej dominacji demograficznej i gospodarczej, paradoksalnie w jeszcze większym stopniu obciążają Austrię. Oczywiście kraj ten nie jest tak ludny, jak Polska, jednak przepaść gospodarcza dzieląca Austrię od Republiki Czeskiej i Słowacji jest znacznie większa i ma poważniejszy charakter.

Nie chodzi tylko o poziom zamożności, choć liczby są nieubłagane - PKB per capita jest blisko dwukrotnie wyższy w Austrii niż w stosunkowo zamożnej na 
tle regionu Republice Czeskiej (pozostałe kraje Europy Środkowej wypadają tylko gorzej). Kluczowa różnica nie dotyczy bowiem wysokości uzyskiwanego dochodu narodowego, lecz sposobu, w jaki jest on osiągany. Austria w tym względzie zdecydowanie należy do Zachodu. Jest więc jednym z motorów ekspansji i w dużym stopniu przyczyniła się do odbudowy gospodarek wychodzących z komunizmu (poprzez inwestycje kapitałowe i transfer nowoczesnych technologii). Najlepiej obrazuje to zestawienie poziomu austriackich inwestycji za granicą z zsumowanymi analogicznymi wartościami dla wszystkich państw Grupy Wyszehradzkiej. Odpowiednio są to 300,70 mld USD oraz 145,27 mld USD. Podobnie wypada porównanie udziału firm krajowych w eksporcie (dla przykładu w Polsce od lat regularnie za jego większość odpowiadają przedsiębiorstwa z kapitałem zagranicznym), poziomu i charakteru bezrobocia etc. Konkurencyjna i nowoczesna gospodarka Austrii jest po prostu w zupełnie innym stadium rozwoju niż Republiki Czeskiej i Słowacji. Niebagatelne znaczenie tej różnicy najłatwiej zrozumieć, analizując wyzwania rozwojowe, które stoją przed wszystkimi państwami Grupy Wyszehradzkiej (a za chwilę także innymi „wspólnikami ich losu”, takimi jak Rumunia, Chorwacja, Bułgaria itd.) w płaszczyźnie ekonomii.

Tabela 1. Zestawienie danych dotyczących PKB, inwestycji zagranicznych i liczby mieszkańców w państwach Grupy Wyszehradzkiej i Austrii

\begin{tabular}{|l|c|c|c|c|c|c|}
\cline { 2 - 7 } & $\begin{array}{c}\text { PKB per } \\
\text { capita } \\
\text { (w USD) }\end{array}$ & $\begin{array}{c}\text { PKB ogó- } \\
\text { łem (w mld } \\
\text { USD) }\end{array}$ & $\begin{array}{c}\text { PKB w licz- } \\
\text { bach bez- } \\
\text { względnych } \\
\text { (w mld } \\
\text { USD) }\end{array}$ & $\begin{array}{c}\text { Inwestycje } \\
\text { zagraniczne } \\
\text { (napływ } \\
\text { w mld } \\
\text { USD) }\end{array}$ & $\begin{array}{c}\text { Inwestycje } \\
\text { za granicą } \\
\text { (wypływ } \\
\text { w mld } \\
\text { USD) }\end{array}$ & $\begin{array}{c}\text { Liczba } \\
\text { miesz- } \\
\text { kańców } \\
\text { (w mln) }\end{array}$ \\
\hline Austria & 45400 & 386,90 & 436,10 & 365,70 & 300,70 & 8,20 \\
\hline $\begin{array}{l}\text { Republika } \\
\text { Czeska }\end{array}$ & 28400 & 299,70 & 200,00 & 140,50 & 22,38 & 10,60 \\
\hline Słowacja & 27700 & 149,90 & 100,10 & 69,76 & 13,09 & 5,40 \\
\hline Węgry & 24300 & 239,90 & 129,70 & 115,60 & 46,10 & 9,90 \\
\hline Polska & 24400 & 941,40 & 552,20 & 273,70 & 63,70 & 38,30 \\
\hline
\end{tabular}

Źródło: opracowanie własne na podstawie https://www.cia.gov/library/publications/the-world-factbook/ (dostęp: 21 kwietnia 2017).

Jakie to wyzwania? Najogólniej mówiąc, można stwierdzić, że Polska i jej sąsiedzi stają z wolna przed koniecznością modyfikacji lub rekonstrukcji polityki gospodarczej, której dalsza realizacja $\mathrm{w}$ dotychczasowej formule nie gwarantuje zachowania notowanej w ostatnim dwudziestopięcioleciu dynamiki rozwoju. Wyczerpanie prostych rezerw wzrostu związanych z niskimi kosztami siły roboczej i jej względnie wysokimi kwalifikacjami grozi, zdaniem ekonomistów, wejściem $\mathrm{w}$ „pułapkę średniego dochodu” (ang. middle income trap). Polega ona na długookresowym spowolnieniu wzrostu gospodarczego i - jak się ocenia — zwykle do- 
tyka państw, których poziom PKB jest zbliżony do notowanego w ostatnich latach w Polsce i na Węgrzech. Dalszy scenariusz zależy przede wszystkim od zdolności danego kraju do wypracowania rozwiązań umożliwiających stopniowy, ewolucyjny rozwój różnych gałęzi własnego przemysłu (gwarantujących w danym okresie wysoką wartość dodaną) poprzez odpowiednie kształtowanie polityk: edukacyjnej, infrastrukturalnej, innowacyjnej czy polityki wsparcia finansowania przedsiębiorstw $^{26}$. To złożone i wymagające odpowiedzialnego i długofalowego programowania polityki gospodarczej wyzwanie podejmowało już wiele państw - czasem z powodzeniem (sztandarowym przykładem jest tu Korea Południowa), innym razem bez (m.in. Argentyna, Wenezuela, Chile).

Przygnębiający „los” przegranych stał się zresztą źródłem licznych teorii kwestionujących paradygmat modernizacji. Przypomnijmy, że w ich myśl państwa półperyferyjne nie mają możliwości dołączenia do centrum ze względu na reprodukcję zależności na płaszczyźnie finansowej (dominacja podmiotów zagranicznych w sektorze bankowym), technologicznej (nieobecność własnej myśli technicznej) i politycznej (wynikającej z obu poprzednich) ${ }^{27}$. Wydaje się, że podobne przekonania leżą u źródeł reform gospodarczych zapoczątkowanych w ostatnich latach przez V. Orbana. Wprowadzane na Węgrzech zmiany w polityce gospodarczej państwa są wyraźnie zorientowane na naprawę kondycji finansów publicznych kosztem zwiększenia obciążeń podatkowych dla firm zagranicznych, odbudowę drobnej przedsiębiorczości, obniżenie kosztów energii, „rehungaryzację” sektora bankowego, obniżenie podatków od osób fizycznych etc. ${ }^{28}$

Naturalnie podobieństwo sytuacji gospodarek Polski, Republiki Czeskiej, Słowacji i Węgier nie oznacza możliwości zastosowania identycznych rozwiązań. Każdy kraj jest inny (różni je m.in. potencjał demograficzny, zasoby, struktura, poziom innowacyjności czy rola w globalnych łańcuchach wartości) i musi ułożyć własny scenariusz rozwojowy ${ }^{29}$. Z pewnością nie da się tego zrobić wspólnie, choć zapewne warto dzielić się doświadczeniami. Można oczywiście - jak pokazuje przykład węgierski - próbować robić to samodzielnie. Łączy się to jednak z ryzy-

26 Por. M.J. Radło, D. Ciesielska-Maciągowska, Przedmowa, [w:] Polska w pułapce średniego dochodu? Perspektywy konkurencyjności polskiej gospodarki i regionów, red. M.J. Radło, D. Ciesielska-Maciągowska, Warszawa 2013, http://www.valuecomesfirst.pl/pulapka-sredniego-dochod/ (dostęp: 6 maja 2018).

27 Syntetyczne omówienie teorii zależności zob. J. Szczepański, Ani Elizjum, ani Hades. Piętnastolecie polskiej transformacji w perspektywie socjologicznych teorii zmiany, [w:] Wspótczesne społeczeństwo polskie. Dynamika zmian, red. J. Wasilewski, Warszawa 2006, s. 22 n.

28 Genezę reform Orbana przedstawia László György w tekście Polityka gospodarcza drugiego rzadu Viktora Orbana, http://www.sobieski.org.pl/wp-content/uploads/Skiba-Rapkiewicz-K\%C4\%99dzierski-red.-W\%C4\%99gry-Orbana-PDF.pdf (dostęp: 29 maja 2015).

29 Doskonale problem dylematów rozwojowych w ramach UE oddaje tytuł wywiadu, jakiego Grzegorzowi Sroczyńskiemu udzielił Marek W. Kozak - Co wymyśli chodnik, czyli polska atrapa rozwoju, http://wyborcza.pl/magazyn/1,145247,18019268,Co_wymysli_chodnik_czyli_polska_atrapa_rozwoju.html?utm_source=facebook.com\&utm_medium $=$ SM\&utm_campaign=FB_Gazeta_ Wyborcza (dostęp: 1 czerwca 2015). 
kiem braku zrozumienia czy wręcz niechęci ze strony partnerów zaangażowanych gospodarczo i w sposób naturalny zainteresowanych maksymalizacją korzyści płynących z dotychczasowego scenariusza rozwojowego (czytaj: przedorbanowskiego). Zasadne jest jednak rozważenie współdziałania na rzecz wypracowania mechanizmów wewnątrz Unii Europejskiej, umożliwiających realizację działań pozwalających skutecznie i trwale dołączyć krajom Grupy Wyszehradzkiej do grona państw partycypujących nie tylko w wysiłkach na rzecz pomnażania dobrobytu w Unii, lecz także w jej modernizacji i płynących z niej korzyściach dla wszystkich członków Wspólnoty.

Uzyskanie większego zrozumienia dla konieczności takiej reorientacji, w kontekście doświadczeń starej Unii z innymi członkami przechodzącymi niezwykle kosztowne dla wspólnoty kryzysy (których symbolicznym i najkosztowniejszym przykładem jest Grecja), wydaje się dzisiaj realne bardziej niż kiedykolwiek.

\section{Podsumowanie}

Choć państwa naszego regionu są od przeszło dekady częścią Unii Europejskiej i NATO, to z pewnością historia Europy Środkowej nie skończyła się z tego powodu. Widoczny i narastający kryzys Grupy Wyszehradzkiej, wynikający z tego pozornego „końca historii”, wymaga wspólnej refleksji nad nowymi problemami, które coraz wyraźniej rysują się przed członkami stowarzyszenia. Narastające różnice interesów między Polską a Republiką Czeską i Słowacją oraz wynikająca stąd reorientacja przez tych ostatnich w stronę zacieśniania relacji z Austrią stanowi poważny sygnał mobilizujący dla Węgier i — w szczególności — dla Polski.

\section{Bibliografia}

Ash T.G., Czy Europa Środkowa istnieje?, „Zeszyty Literackie” 1987, nr 17.

Bahna M., Krajiny kultúrne najpodobnejšie a krajiny pre Slovensko nebezpečné. Čo sa zmenilo v období 1996-2014?, Sociologický ústav SAV, http://www.sociologia.sav.sk/cms/uploaded/2172_ attach_1_krajiny_podobne_a_krajiny_nebezpecne.pdf.

Chlebowczyk J., Procesy narodowotwórcze we wschodniej Europie środkowej w dobie kapitalizmu, Warszawa-Kraków 1975.

Czarnocki A., Europa Środkowa. Europa Środkowo-Wschodnia: geopolityczne a historyczno-kulturowe rozumienie pojęć, „Annales Universitatis Mariae Curie-Skłodowska. Sectio K: Politologia” 1994, nr 1.

Deklaracja Wyszehradzka 1991, http://www.visegradgroup.eu/documents/visegrad-declarations/ visegrad-declaration-110412-2.

Gniazdowski M., Groszkowski J., Sadecki A., Wyszehradzka kakofonia wobec konfliktu rosyjsko-ukraińskiego, http://www.osw.waw.pl/pl/publikacje/analizy/2014-09-10/wyszehradzka-kakofonia -wobec-konfliktu-rosyjsko-ukrainskiego.

Gniazdowski M. et al., Strategia Unii Europejskiej dla regionu Dunaju. Implikacje dla Polski i Grupy Wyszehradzkiej, Warszawa 2011. 


\section{Europa Środkowa — od idei literacko-kawiarnianej do koncepcji politycznych}

Grajewski A., Trudne pojednanie. Stosunki czesko-niemieckie 1989-1999, Warszawa 2000.

Groszkowski J., Czeskie dylematy wobec Rosji i NATO, http://www.osw.waw.pl/pl/publikacje/analizy/2015-04-01/czeskie-dylematy-wobec-rosji-i-nato.

Groszkowski J., Deklaracja sławkowska. Nowy format współpracy regionalnej, http://www.osw.waw.pl/ pl/publikacje/analizy/2015-02-04/deklaracja-slawkowska-nowy-format-wspolpracy-regionalnej.

Grupa Wyszehradzka wspiera Partnerstwo Wschodnie, http://www.osw.waw.pl/pl/publikacje/analizy/2011-06-29/grupa-wyszehradzka-wspiera-partnerstwo-wschodnie.

György L., Polityka gospodarcza drugiego rzadu Viktora Orbana, http://www.sobieski.org.pl/wp-content/uploads/Skiba-Rapkiewicz-K\%C4\%99dzierski-red.-W\%C4\%99gry-Orbana-PDF.pdf.

Havel V., Siła bezsilnych, [w:] Hrabal, Kundera, Havel... antologia czeskiego eseju, oprac. J. Baluch, Kraków 2001.

KozakM.W., Co wymyślichodnik, czylipolskaatrapa rozwoju, http://wyborcza.pl/magazyn/1,145247, 18019268,Co_wymysli_chodnik_czyli_polska_atrapa_rozwoju.html?utm_source=facebook. com\&utm_medium=SM\&utm_campaign=FB_Gazeta_Wyborcza.

Krasiński A., Wprowadzenie, [w:] Między Wschodem i Zachodem, konwersatorium „Polska w Europie", Warszawa 1988.

Kundera M., Zachód porwany albo tragedia Europy Środkowej, „Zeszyty Literackie” 1984, nr 5.

Kymlicka W., Nation-building and minority rights: comparing West and East, „Journal of Ethnic and Migration Studies" 2000, nr 2.

Palade M., Uśmierciliśmy Grupę Wyszehradzką, http://www.mysl-polska.pl/node/372.

Radło M.J., Ciesielska-Maciągowska D., Przedmowa, [w:] Polska w pułapce średniego dochodu? Perspektywy konkurencyjności polskiej gospodarki i regionów, red. M.J. Radło, D. Ciesielska-Maciągowska, Warszawa 2013.

Skórczewski D., Polska skolonizowana, Polska zorientalizowana. Teoria postkolonialna wobec „innej Europy”, „Porównania” 2009, nr 6.

Stosunek do innych narodów, CBOS NR 14/2015, www.cbos.pl.

Sympatie ceské verejnosti k nekterým zemím - leden 2015, Centrum pro výzkum verejného mínení, 20. února 2015, http://www.sociologia.sav.sk/cms/uploaded/2172_attach_1_krajiny_podobne_a_krajiny_nebezpecne.pdf.

Szczepański J., Ani Elizjum, ani Hades. Piętnastolecie polskiej transformacji w perspektywie socjologicznych teorii zmiany, [w:] Współczesne społeczeństwo polskie. Dynamika zmian, red. J. Wasilewski, Warszawa 2006.

Velikonja M., Slovenian and Polish religio-national mythologies: A comparative analysis, „Religion, State \& Society" 2003, nr 3.

Wereszycki H., Pod berlem Habsburgów. Zagadnienia narodowościowe, Kraków 1986.

Wojna na Ukrainie i działania Rosji dziela Grupe Wyszehradzką, http://www.money.pl/gospodarka/ unia-europejska/wiadomosci/artykul/wojna-na-ukrainie-i-dzialania-rosji-dziela,189,0,1741245. html.

Zenderowski R., Europa Środkowa jako „ucieczka przed Wschodem” czy „pomost” między Wschodem i Zachodem?, [w:] Europa Środkowa: wspólnota czy zbiorowość?, red. R. Zenderowski, Wrocław-Warszawa-Kraków 2004.

Zenderowski R., Pomiędzy Wschodem a Zachodem?, „Przegląd Zachodni” 2004, nr 3. 